\title{
Homeobox Protein Hox-C13
}

National Cancer Institute

\section{Source}

National Cancer Institute. Homeobox Protein Hox-C13. NCI Thesaurus. Code C97579.

Homeobox protein Hox-C13 (330 aa, $\sim 35 \mathrm{kDa}$ ) is encoded by the human HOXC13 gene.

This protein plays a role in transcriptional regulation during development. 